\title{
Expression and prognostic value of the cell polarity PAR complex members in thyroid cancer
}

\author{
CHIARA TUCCILLI ${ }^{*}$, ENKE BALDINI ${ }^{2 *}$, YANNICK ARLOT-BONNEMAINS ${ }^{3}$, FRANK CHESNEL $^{3}$, \\ SALVATORE SORRENTI $^{2}$, CORRADO DE VITO ${ }^{4}$, ELEONORA D'ARMIENTO ${ }^{1}$, ALESSANDRO ANTONELLI ${ }^{5}$, \\ POUPAK FALLAHI ${ }^{5}$, SARA WATUTANTRIGE ${ }^{6}$, FRANCESCO TARTAGLIA ${ }^{2}$, SUSI BAROLLO ${ }^{6}$, \\ CATERINA MIAN ${ }^{6}$, STEFANO ARCIERI $^{2}$, DOMENICO MASCAGNI ${ }^{2}$, DANIELE PIRONI $^{2}$, MARCO BONONI $^{7}$, \\ MASSIMO VERGINE ${ }^{2}$, MASSIMO MONTI ${ }^{2}$, ANGELO FILIPPINI ${ }^{2}$ and SALVATORE ULISSE ${ }^{2}$
}

\begin{abstract}
Departments of ${ }^{1}$ Experimental Medicine and ${ }^{2}$ Surgical Sciences, 'Sapienza' University of Rome, Rome, Italy; ${ }^{3}$ CNRS-UMR 6290 (IGDR) Université Rennes 1, Rennes, France; ${ }^{4}$ Department of Public Health and Infectious Diseases, 'Sapienza' University of Rome, Rome; ${ }^{5}$ Department of Clinical and Experimental Medicine, University of Pisa, Pisa; ${ }^{6}$ Department of Medicine, University of Padua, Padua; ${ }^{7}$ Department of Surgery 'Pietro Valdoni', 'Sapienza' University of Rome, Rome, Italy
\end{abstract}

Received November 10, 2016; Accepted January 11, 2017

DOI: 10.3892/ijo.2017.3907

\begin{abstract}
Establishment and maintenance of the apicalbasal cell polarity, required for proper replication, migration, specialized functions and tissue morphogenesis, relies on three evolutionary conserved complexes: PAR, CRUMBS and SCRIBBLE. Loss of cell polarity/cohesiveness (LOP/C) is implicated in cancer progression, and members of the polarity complex have been described as either oncogenes or oncosuppressors. However, no information on their role in thyroid cancer (TC) progression is available. In the present study, we evaluated the gene expression of the PAR complex members $a P K C \iota, P A R D 3 \alpha / \beta$ and $P A R D 6 \alpha / \beta / \gamma$ in 95 papillary TC (PTC), compared to their normal matched tissues and in 12 anaplastic TC (ATC). The mRNA and protein levels of investigated genes were altered in the majority of PTC and ATC tissues. In PTC, univariate analysis showed that reduced expression of $a P K C \iota$, $P A R D 3 \beta$ and PARD $6 \gamma$ mRNAs is associated with increased tumor size, and the reduced expression of $P A R D 3 \beta$ mRNA is associated also with recurrences. Multivariate analysis demonstrated that the presence of lymph node metastasis at diagnosis and the reduced expression of $P A R D 3 \beta$ are independent risk factors for recurrences, with hazard ratio, respectively, of 8.21 $(\mathrm{P}=0.006)$ and $3.04(\mathrm{P}=0.029)$. The latter result was confirmed
\end{abstract}

Correspondence to: Professor Salvatore Ulisse, Department of Surgical Sciences, 'Sapienza' University of Rome, Viale Regina Elena 324, I-00161 Rome, Italy

E-mail: salvatore.ulisse@uniroma1.it

*Contributed equally

Key words: thyroid, papillary thyroid carcinoma, anaplastic thyroid carcinoma, PAR complex, apico-basal polarity, aPKC, PARD3, PARD6 by the Kaplan-Meier analysis, which evidenced the association between decreased PARD $3 \beta$ mRNA levels and shorter disease-free interval. In conclusion, we demonstrated that the expression of PAR complex components is deregulated in the majority of PTC and there is a general trend towards their reduction in ATC tissues. Moreover, a prognostic value for the $P A R D 3 \beta$ gene in PTCs is suggested.

\section{Introduction}

Polarity is defined as the persistent asymmetrical and ordered distribution of structures along an axis, and represents a basic property of organisms, organs, tissues and cells (1). Different types of polarity exist, like the planar cell polarity (PCP), the apical-basal polarity (ABP) and the front-rear polarity (FRP). The ABP is the most studied and best described type of cell polarity, and is a peculiar characteristic of epithelial and endothelial cells (2). It determines the formation of two cellular regions: the apical one faces the lumen and the basal one is in contact with the basement membrane. The establishment and maintenance of ABP is due to the interaction and subcellular localization of three evolutionary conserved protein complexes, CRUMBS, PAR and SCRIBBLE, that determine the domains of polarized cells, i.e. the apical, the apical-lateral and the basallateral districts, respectively. The three polarity complexes participate also in the formation and stabilization of the tight junctions (TJs) and adherent junctions (AJs), which in turn have a role in preserving the ABP and tissue homeostasis (3-6).

Over the last decades, various research has clarified the role of the polarity complexes starting from the study of the model organisms Caenorhabditis elegans and Drosophila melanogaster (7-9). The comprehension of the molecular functions of these complexes led to consider cell polarity the prerequisite for the organogenesis, and essential to ensure tissue homeostasis by controlling proliferation, asymmetric division, migration and specialized cell functions (5). Not surprisingly, 
both neoplastic transformation and cancer progression have been associated to loss of cell polarity/cohesiveness (LOP/C), considered a cancer hallmark (10). Moreover, LOP/C is implicated in the epithelial-mesenchymal transition (EMT), strictly connected with the metastasis development (10). Deregulated expression of ABP complex members has been described in several cancer types, in which they have been identified as either oncosuppressors or oncogenes (4).

In the present study, we focused attention on the one having the widest range of functions, i.e. the PAR (PARtitioning defective) complex (11). It is composed by a core of three proteins: PAR3, PAR6 and the atypical protein kinase $\mathrm{C}$, aPKC. In mammals, paralogous genes have been described: $P A R D 3 \alpha / \beta$, $P A R D 6 \alpha / \beta / \gamma, a P K C \zeta$ and $a P K C \iota$, expressed at different levels during the embryonal development and in adult tissues (12-15). $P A R D 3 \alpha$ localizes at TJs formation areas and acts as scaffold for aPKC and PARD6 to induce TJs assembly, but participates also in the regulation of other cellular processes, including migration, cell cycle and asymmetrical division by interacting with other molecules (5). PARD $3 \beta$ does not interact with the aPKC, although sharing the cellular localization with $P A R D 3 \alpha$, thus, it does not seem to participate in formation of TJs $(3,16)$. Regarding the three PARD6 forms, PARD6 $\alpha$ is present both at TJs and in the cytosol, PARD6 $\beta$ is localized in the cytosol and PARD6 $\gamma$ focuses at TJs. Some studies have described other cellular locations of PARD6 $\alpha$ and $P A R D 6 \gamma$, that is nucleus and centriole, respectively $(17,18)$. Like PARD3, PARD6 acts as scaffold protein, and its principal role is to connect aPKC to PARD $3 \alpha$ and to its downstream targets, but the different subcellular localizations of the three forms indicate further functions $(17,18)$. Proteins $a P K C \zeta$ and $a P K C \iota$ are both localized in the cytoplasm and at the TJs, and phosphorylate numerous substrates, among which PARD3 (3).

Alterations in the expression levels of the PAR complex members have been reported in many types of human cancer, like the esophageal squamous cell carcinoma, the non-small cell lung carcinoma, the ovarian cancer and the breast carcinoma (19). Moreover, an oncogenic/oncosuppressor context-dependent role of PAR members emerged from functional studies (19). However, there is a lack of information on PAR gene expression and role in epithelial thyroid cancer (TC) progression.

TC represents the most common endocrine malignancy accounting for roughly $1 \%$ of all human cancers, and its incidence has been increasing over the last decades, mainly due to the improved ability to diagnose malignant transformation in small non-palpable thyroid nodules $(20,21)$. More than $90 \%$ of thyroid carcinomas are represented by the differentiated papillary (PTC) and follicular (FTC) histotypes, whereas the invariably fatal undifferentiated (anaplastic) thyroid carcinoma (ATC) accounts for aproximately $1 \%$ of TC $(22,23)$. Although derived from the same cell type, the epithelial thyroid tumors show specific histological features, biological behavior and degree of differentiation as a consequence of different genetic alterations $(24,25)$. One of the most common in PTC is the $B R A F^{V 600 E}$ mutation $(26,27)$, that associates with clinicopathological features, as advanced stage, extrathyroidal extension, lymph node and distant metastases (28). Some authors evidenced polarity alterations in TC, and it has been shown that PTC patients with tumors retaining cellular polarity had a better course than those exhibiting LOP/C features (29-31).

In the present study, we analyzed the expression of the PAR complex members in 95 PTC compared against normal tissues and 12 ATC tissues. Data from PTC patients were then correlated with clinicopathological parameters and patients' disease-free interval.

\section{Materials and methods}

Tissue samples, histology and staging of patients. Normal and matched PTC tissues were obtained from surgical specimens of 95 patients (19 males and 76 females, age range 11-83 years, median 44 years) who underwent total thyroidectomy at the Department of Surgical Sciences, 'Sapienza' University of Rome (38 patients) or at the Department of Medicine, University of Padua (57 patients); while ATC tissues were collected from surgical specimens of 12 patients ( 4 males and 8 females, age range 57-79 years, median 69 years) who had surgery at the Department of Medicine, University of Padua (7 patients) or at Department of Clinical and Experimental Medicine of Pisa (5 patients). All the patients gave their informed consent, and the study was approved by the local ethics committee (protocol no. 2615). Tissue samples were collected, frozen in liquid nitrogen and stored at $-80^{\circ} \mathrm{C}$. Of the 95 patients, 72 exhibited classical, 18 follicular, 2 tall cell and 2 oncocytic variants. The histological diagnoses were made independently by two different histopathologists according to the World Health Organization classification (32). At the time of surgery lymph node metastases were found in 39 patients. Following TNM staging, 59 patients were at stage I, 1 at stage II, 29 at stage III and 6 at stage IV. Approximately 40-50 days later all the patients underwent radioiodine therapy followed by thyroid hormone replacement therapy. To ascertain their disease-free condition, 4-5 months after intervention all the patients underwent neck ultrasound and serum $\mathrm{Tg}$ measurement. Recurrences were diagnosed by measurement of serum Tg levels either in basal conditions or following recombinant human TSH stimulation; FNA cytology and/or Tg determination in the FNA wash-out from lymph nodes; ${ }^{131}$ I whole body scan; histological analysis following surgical resection of the lesion. The follow-up included 79 patients (mean 57.1 \pm 36.7 months, range 5-141 months), 52 of whom were at TNM stage I. During the follow-up 16 recurrences were recorded. Regarding ATC patients, they all died from the disease (survival time range 1-25 months, median 6 months).

Determination of BRAF ${ }^{V 600 E}$ mutation. Genomic DNA was extracted from the frozen tissues using the DNeasy Blood and Tissues kit (Qiagen, Milan, Italy) according to the manufacturer's protocol. The BRAF status of exon 15 was assessed by both direct sequencing and mutant allele-specific PCR amplification for the T to A substitution at nucleotide 1799 (V600E), using the procedure previously described (33).

Extraction and analysis of $m R N A$. Frozen normal and tumor thyroid tissues were homogenized with the ultra-turrax, and total RNA extracted applying the acid guanidinium thiocyanate-phenol-chloroform method (34). The first cDNA strand was synthesized from $5 \mu \mathrm{g}$ of RNA with M-MLV reverse 
Table I. Sequences, genomic positions and amplicon sizes of the primers used in qRT-PCR for the target and reference genes.

\begin{tabular}{|c|c|c|c|}
\hline Gene & Primer sequence & Exons & Amplicon lenght (bp) \\
\hline GAPDH & $\begin{array}{l}\text { Forward: 5'-ATCATCAGCAATGCCTCCTG-3' } \\
\text { Reverse: 5'-GGCCATCCACAGTCTTCTG-3' }\end{array}$ & $\begin{array}{c}6-7 \\
8\end{array}$ & 136 \\
\hline$R P L 13 a$ & $\begin{array}{l}\text { Forward: 5'-ACCGTGCGAGGTATGCTG-3' } \\
\text { Reverse: 5'-TAGGCTTCAGACGCACGAC-3' }\end{array}$ & $\begin{array}{c}4-5 \\
6\end{array}$ & 148 \\
\hline$S D H A$ & $\begin{array}{l}\text { Forward: 5'-GCATAAGAACATCGGAACTGC-3' } \\
\text { Reverse: 5'-GGTCGAACGTCTTCAGGTG-3' }\end{array}$ & $\begin{array}{l}12 \\
13\end{array}$ & 147 \\
\hline$a P K C \iota$ & $\begin{array}{l}\text { Forward: 5'-CTAAGGAACGATTGGGTTGTC-3' } \\
\text { Reverse: 5'-TGAGAATCAAAGTTGTCCAAACC-3' }\end{array}$ & $\begin{array}{l}16 \\
17\end{array}$ & 126 \\
\hline$P A R D 3 \alpha$ & $\begin{array}{l}\text { Forward: 5'-GATAATCAGAGGCAGGGGATG-3' } \\
\text { Reverse: 5'-TGTGTCTTCTTCCAAGGTCTCC-3' }\end{array}$ & $\begin{array}{l}19 \\
20\end{array}$ & 115 \\
\hline$P A R D 3 \beta$ & $\begin{array}{l}\text { Forward: 5'-AACCACCTCTAGGCGAAATG-3' } \\
\text { Reverse: 5'-AGAATGTGGTGTTGGAGAAGG-3' }\end{array}$ & $\begin{array}{l}12 \\
13\end{array}$ & 139 \\
\hline$P A R D 6 \alpha$ & $\begin{array}{l}\text { Forward: 5'-CCTCACCAACGACGACAG-3' } \\
\text { Reverse: 5'-AGAGAGTTGGAGGCAAAAGC-3' }\end{array}$ & $\begin{array}{l}2 \\
3\end{array}$ & 107 \\
\hline$P A R D 6 \beta$ & $\begin{array}{l}\text { Forward: 5'-TTTCAACGGCCAATCCAC-3' } \\
\text { Reverse: 5'-TGTCAGGACGCAATACGTTG-3' }\end{array}$ & $\begin{array}{l}1 \\
2\end{array}$ & 147 \\
\hline$P A R D 6 \gamma$ & $\begin{array}{l}\text { Forward: 5'-TCAGACCTTGCGATTCTACG-3' } \\
\text { Reverse: 5'-TTGGAGATATGGTGGGTGTG-3' }\end{array}$ & $\begin{array}{l}1 \\
2\end{array}$ & 147 \\
\hline
\end{tabular}

aPKC, atypical protein kinase C; PARD3, partitioning defective 3; PARD6, partitioning defective-6; GAPDH, glyceraldehyde-3-phosphate dehydrogenase; $R P L 13 a$, ribosomal protein L13a; SDHA, succinate dehydrogenase complex, subunit A.

transcriptase and anchored oligo(dT)23 primers (Sigma Chemicals). Parallel controls for DNA contamination were carried out omitting the reverse transcriptase. The templates obtained were used for quantitative PCR amplifications of the different members of the PAR complex and three different housekeeping genes (GAPDH, RPL13A and SDHA), previously shown to be the most stable among 7 candidate reference genes $(35,36)$, employing the LightCycler instrument (Roche Diagnostics, Mannheim, Germany), the SYBR Premix Ex Taq II (Tli RNase H Plus) (Takara, Shiga, Japan) and specific primers listed in Table I. Amplicon specificities were checked by automated DNA sequencing (Bio-Fab Research, Rome, Italy), evaluation of melting temperatures, and electrophoresis on $2 \%$ agarose gel containing ethidium bromide. Standard curves for all genes were created with 5-fold dilutions of mixed human thyroid tissue cDNA. Calculation of data for PTC was performed by the Relative Expression Software Tool (REST 2009) using a normalization factor computed as the geometric media of the 3 reference genes, as previously described $(35,36)$. The fold change in the mRNA levels of the different PAR complex components was referred for each PTC sample to its normal counterpart. Regarding ATC samples, for which the normal matched tissues were not available, they were compared to PTC tissues through the $\Delta \Delta \mathrm{Ct}$ method. In the latter, the $\Delta \mathrm{Ct}$ of each gene was calculated using the geometric mean of the above mentioned housekeeping genes, whose expression was proven to be stable also between PTC and ATC in preliminary experiments (data not shown). The $\Delta \Delta \mathrm{Ct}$ were computed by subtracting the $\Delta \mathrm{Ct}$ of each sample the $\Delta \mathrm{Ct}$ of the sample showing the lowest gene expression (37).
Western blot analysis. Normal and PTC tissue samples from 12 patients were homogenized in RIPA buffer $(50 \mathrm{mM}$ Tris- $\mathrm{HCl}$ $\mathrm{pH} 7.4,1 \%$ NP-40, $0.5 \%$ sodium deoxycholate, $150 \mathrm{mM}$ sodium chloride, $1 \mathrm{mM}$ EDTA, $1 \mathrm{mM}$ sodium fluoride, $1 \mathrm{mM}$ AEBSF, $10 \mu \mathrm{g} / \mathrm{ml}$ aprotinin, $10 \mu \mathrm{g} / \mathrm{ml}$ leupeptin, $1 \mathrm{mM}$ sodium orthovanadate, $10 \mathrm{mM}$ sodium pyrophosphate in $\mathrm{ddH}_{2} \mathrm{O}$ ) by Turrax, centrifuged at 10,000 rpm for $10 \mathrm{~min}$ and frozen to $-80^{\circ} \mathrm{C}$. Protein concentrations in the cell extracts were determined by the Bradford assay (38). Aliquot of $50 \mu \mathrm{g}$ of tissue extracts were supplemented with 5X Laemmli buffer $(120 \mathrm{mM}$ Tris- $\mathrm{HCl}, \mathrm{pH} 6.8,2 \%$ SDS, $10 \%$ glycerol, $0.01 \%$ bromophenol blue) containing $5 \%$ of mercaptoethanol, heated at $95^{\circ} \mathrm{C}$ for $5 \mathrm{~min}$, electrophoresed on polyacrylamide gels and transferred onto nitrocellulose membranes using the Bio-Rad Mini TransBlot Cell system. The membranes were then washed with TBST (50 mM Tris- $\mathrm{HCl}, \mathrm{pH} 7.5,150 \mathrm{mM} \mathrm{NaCl}$ and $0.05 \%$ Tween-20) and saturated with 5\% low fat milk in TBST for $2 \mathrm{~h}$ at room temperature. Incubations with primary antibodies were performed for the identification of the different components of the PAR complex in $2.5 \%$ low fat milk in TBST at $4^{\circ} \mathrm{C}$ overnight. The polyclonal antibodies raised against $P A R D 3 \alpha$ (1:1,000, NBP1-88861; Novus Biologicals), PARD3 $\beta$ (1:1,000, Ab122264; Abcam), aPKCı (1:1,000, sc-11399; Santa Cruz Biotechnology), PARD6 $\alpha$ (1:1,000, sc-25525; Santa Cruz Biotechnology), PARD6 $\beta$ (1:1,000, sc-67392; Santa Cruz Biotechnology) and PARD6 $\gamma$ (1:2,000, orb35046; Biorbyt, Cambridge, UK) were detected with anti-rabbit horseradish peroxidase conjugated secondary antibody (1:20,000; Jackson ImmunoResearch Laboratories, West Grove, PA, USA). Sample loadings in the different western blots were controlled 

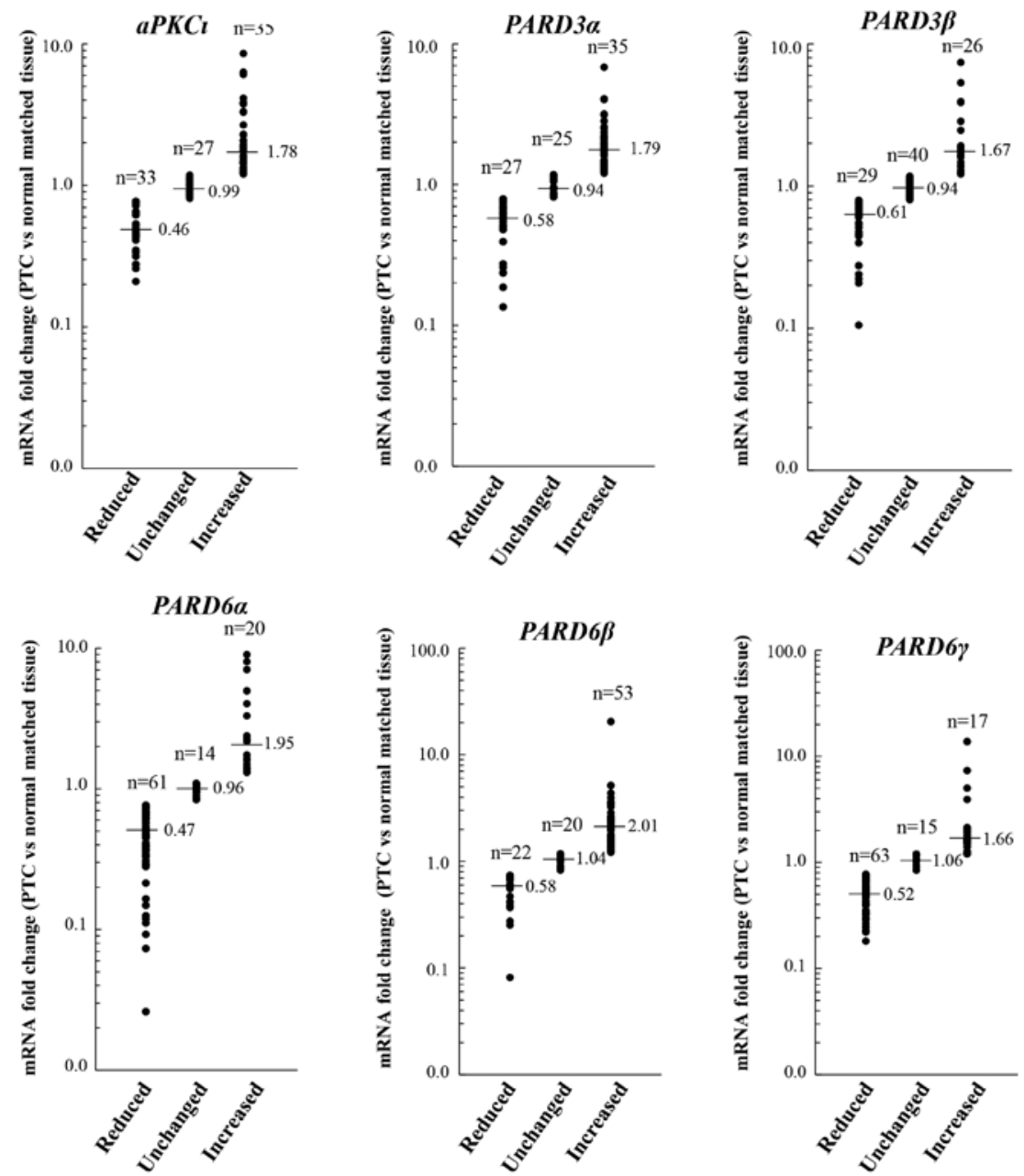

Figure 1. Levels of PAR complex members mRNA in PTC patients. The fold changes were calculated by normalizing the qPCR results from PTC tissues with their normal counterpart. In the graph, the small bars indicate the median values, ' $n$ ' is the number of patients who presented reduced, unchanged and increased mRNA values of the investigated genes.

with the monoclonal anti-GAPDH (1:20,000, ab8245; Abcam). The western blots were revealed by Chemiluminescence SuperSignal kit from Pierce (Rockford, IL, USA).

Statistical analysis. First, the Shapiro-Wilk test was used to check whether the mRNA data were normally distributed, and if they were not, the non-parametric Mann-Whitney U-test was used to calculate the statistical significance of differences in the expression levels of the different PAR complex components in female vs. male patients; in classical PTC variant vs. other variants; in $B R A F^{V 600 E}$ mutated vs. wild-type PTC; in metastatic (N1) vs. non-metastatic (N0) PTC; in T1-2 vs. T3-4 tumor sizes; in TNM I-II vs. III-IV stages; in presence or absence of recurrence; in PTC patients group vs. ATC patients group. The correlation of PAR mRNAs with each other, and with patient's age was evaluated by the Spearman's Rho test. The Cox regression stepwise with backward elimination analysis was used to assess the independent association of patient's age, tumor size, histological variants, lymph node metastasis and PAR complex components mRNAs with recurrences. The impact of each PAR gene expression on disease-free interval was assessed by the Kaplan-Meier analysis combined with Mantel-Cox log-rank. For the latter, and for the Cox regression, values were classified based on the following criteria: fold change $>1.2$ as 'increased'; fold change $<0.8$ as 'decreased'; $\geq 0.8$-fold change $\leq 1.2$ as 'unvaried'. All statistical analyses were carried out with the SPSS software (IBM, Armonk, NY, USA) and the results were considered significantly different at $\mathrm{P}$-value of $<0.05$.

\section{Results}

Expression of PAR complex components in papillary (PTC) and anaplastic (ATC) thyroid cancer tissues. The analyses of mRNA levels of PAR complex components in PTC samples, compared to normal matched tissues, revealed that the expression of all transcripts was deregulated (i.e. reduced or increased) in the majority of cases (Fig. 1). In particular, $a P K C \iota$ was reduced in 33/95 (34.7\%) cases, unchanged in $27 / 95(28.4 \%)$ cases and increased in 35/95 (36.8\%) cases; PARD3 $\alpha$ was reduced in $27 / 95$ (28.4\%) cases, unchanged in $25 / 95(26.3 \%)$ cases and increased in 35/95 (36.8\%) cases; PARD $3 \beta$ was reduced in $29 / 95$ (30.5\%) cases, unchanged in $40 / 95(42.1 \%)$ cases and increased in 26/95 (27.4\%) cases; PARD6 $\alpha$ was reduced in 61/95 (64.2\%) cases, unchanged in $14 / 95(14.7 \%)$ cases and increased in 20/95 (21.1\%) cases; 
Table II. Correlation analysis among mRNA levels of PAR complex components.

\begin{tabular}{|c|c|c|c|c|c|c|}
\hline & \multicolumn{6}{|c|}{ Correlation coefficients and P-values } \\
\hline & $a P K C \iota$ & $P A R D 3 \alpha$ & $P A R D 3 \beta$ & $P A R D 6 \alpha$ & $P A R D 6 \beta$ & $P A R D 6 \gamma$ \\
\hline \multirow[t]{2}{*}{$a P K C \iota$} & 1.000 & 0.718 & 0.439 & 0.279 & 0.489 & 0.497 \\
\hline & - & $<0.0001$ & $<0.0001$ & 0.006 & $<0.0001$ & $<0.0001$ \\
\hline \multirow[t]{2}{*}{$P A R D 3 \alpha$} & & 1.000 & 0.555 & 0.367 & 0.507 & 0.538 \\
\hline & & - & $<0.0001$ & $<0.0001$ & $<0.0001$ & $<0.0001$ \\
\hline \multirow[t]{2}{*}{$P A R D 3 \beta$} & & & 1.000 & 0.347 & 0.570 & 0.667 \\
\hline & & & - & 0.001 & $<0.0001$ & $<0.0001$ \\
\hline \multirow[t]{2}{*}{$P A R D 6 \alpha$} & & & & 1.000 & 0.150 & 0.371 \\
\hline & & & & - & 0.142 & $<0.0001$ \\
\hline \multirow[t]{2}{*}{$P A R D 6 \beta$} & & & & & 1.000 & 0.466 \\
\hline & & & & & - & $<0.0001$ \\
\hline \multirow[t]{2}{*}{ PARD6 $\gamma$} & & & & & & 1.000 \\
\hline & & & & & & - \\
\hline
\end{tabular}
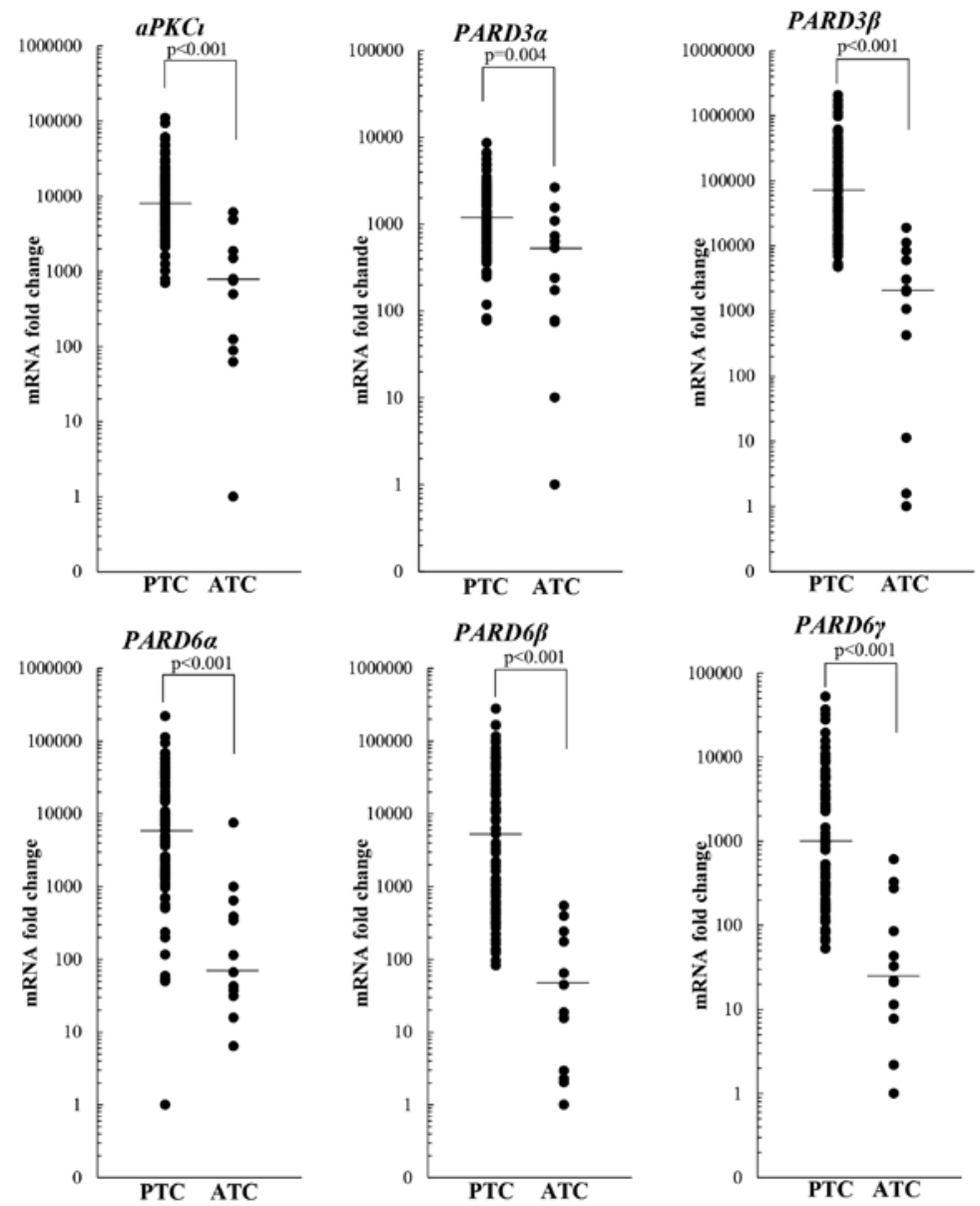

Figure 2. Comparison of mRNA expression levels of the PAR complex members between PTC and ATC tissues. Messenger RNA level in ATC tissues were compared to that of PTC through the $\Delta \Delta \mathrm{Ct}$ method. The statistical evaluation of the data was performed with the non-parametric Mann-Whitney test. The small bars in the graph indicate the median values.

PARD6 $\beta$ was reduced in 22/95 (23.2\%) cases, unchanged in 20/95 (21.1\%) cases and increased in 53/95 (55.8\%) cases; and PARD6 $\gamma$ was reduced in 63/95 $(66.3 \%)$ cases, unchanged in $15 / 95(15.8 \%)$ cases and increased in 17/95 (17.9\%) cases.
We next evaluated whether the expression of the PAR genes correlated with each other. As shown in Table II, with the exception of the couple PARD $6 \alpha / P A R D 6 \beta$, a significant positive correlation was found between all the mRNAs. 

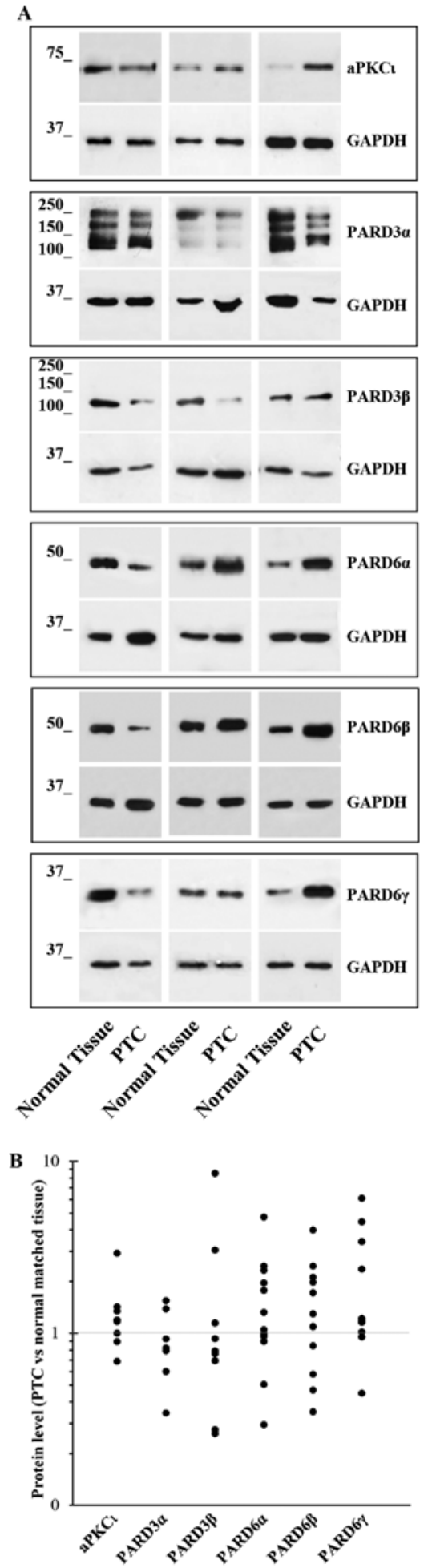

Figure 3. Levels of PAR complex proteins in 12 PTC patients. (A) The figure shows representative cases of reduced, unvaried and increased protein levels in 3 PTC tissues compared to normal matched tissues. (B) The graphic shows the distribution of proteins levels into PTC patients tissues normalized against their normal counterpart.

The transcripts levels were investigated also in 12 ATC tissues. The results showed that the expression of all genes analyzed was significantly lower in ATC compared to PTC tissues (Fig. 2).

Twelve PTC tissue specimens were used to prepare protein extracts, and western blot experiments were carried

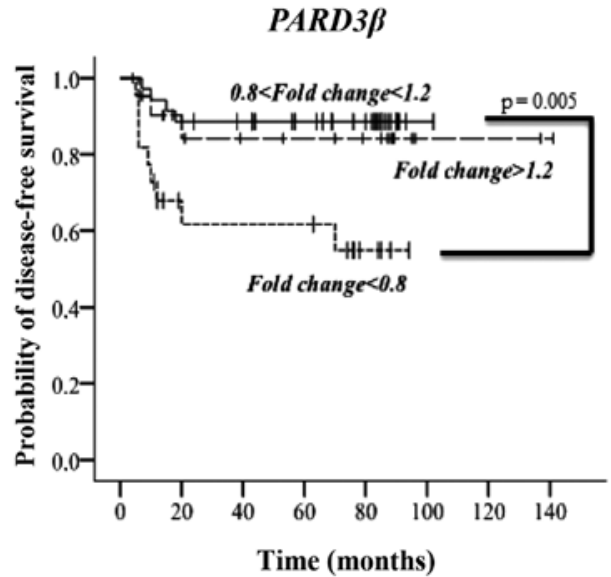

Figure 4. Levels of PARD3 $\beta$ mRNA and disease-free interval (DFI) in PTC patients. Kaplan-Meier analysis combined with Mantel-Cox log-rank statistical test, performed on 79 PTC patients followed-up from 5 to 141 months.

out for the different PAR complex members. The results confirmed their deregulation (i.e. reduction or increase) in the majority of PTC tissues (Fig. 3). Unfortunately, only 12 PTC specimens were large enough to permit both RNA and proteins extraction, so their number was too small to perform any statistical analysis, including the correlation between mRNA and protein levels.

BRAF ${ }^{V 600 E}$ mutation and PAR complex components expression in PTC tissues. To assess the effect of $B R A F^{V 600 E}$ mutation on PAR complex member expression, we analyzed the mRNA levels of each PAR gene in 76 PTC tissues for which it was possible to check the $B R A F$ gene status. Of these, $37(48.7 \%)$ PTC harbored the $B R A F^{V 600 E}$ mutation while 39 had the wild-type $B R A F$. The result of univariate analysis, reported in Table III, showed that the $B R A F^{V 600 E}$ mutation associated only with PARD6 $\beta$ gene transcription in PTC tissues.

Prognostic relevance of PAR complex member expression in PTC patients. No association between the expression, at the mRNA level, of PAR complex members and gender, age, tumor histology, lymph node metastasis and TNM stage was observed (Table III). However, a significant association emerged between reduced mRNA levels of $a P K C \iota, P A R D 3 \beta$ and $P A R D 6 \gamma$ and increased tumor size (Table III). The univariate statistical analysis evidenced also an association between higher $P A R D 6 \beta$ mRNA levels and $B R A F^{V 600 E}$ mutation. In addition, low levels of $P A R D 3 \beta$ significantly associated with tumor relapse (Table III). Notably, the Kaplan-Meier analysis demonstrated a significant correlation only for $P A R D 3 \beta$ mRNA levels with the disease-free interval (DFI) (Fig. 4). The latter is represented for patients grouped in three categories based on the PARD $3 \beta$ mRNA fold changes: increased, unvaried and decreased. As evident, lower PARD3 $\beta$ mRNA levels negatively influenced the DFI. Besides, the multivariate statistical analysis indicated $P A R D 3 \beta$ and lymph node metastasis at diagnosis as the only variables independently associated to DFI, with a hazard ratio, respectively, of 3.04 (95\% CI, 1.12-8.24, P=0.029) and 8.21 (95\% CI, 1.85-35.53, $\mathrm{P}=0.006$ ) (Table IV). 


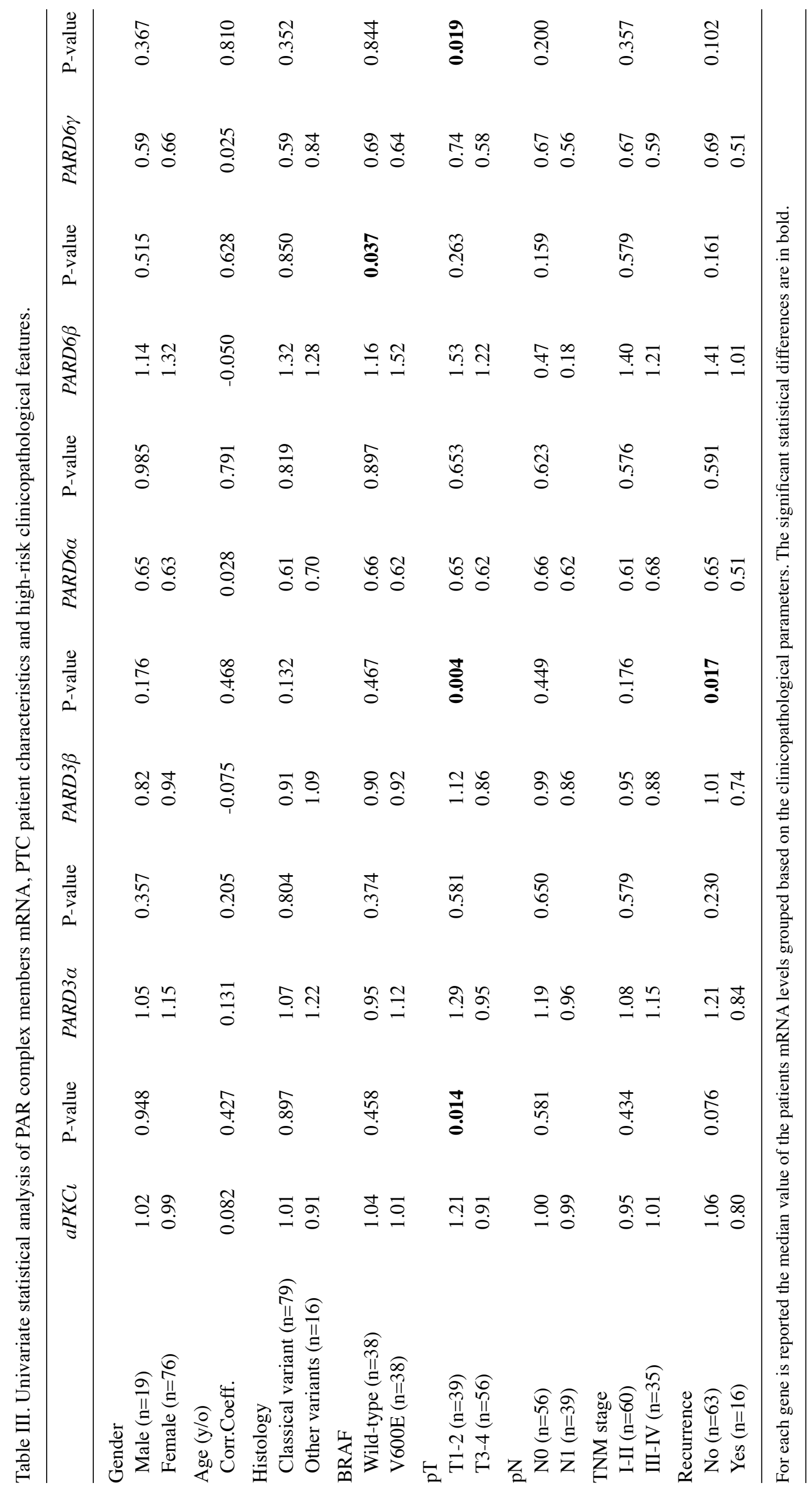


Table IV. Cox regression stepwise with backward elimination analysis.

\begin{tabular}{lccc}
\hline Variables & HR & $95 \%$ CI & P-value \\
\hline Decreased PARD3 $\beta$ mRNA & 3.04 & $1.12-8.24$ & 0.029 \\
Lymph node metastasis & 8.21 & $1.85-35.53$ & 0.006 \\
\hline
\end{tabular}

The table presents only the statistically significant results of the multivariate analysis of the different clinicopathological parameters and PAR complex components mRNAs with cancer recurrence in PTC patients. HR, hazard ratio.

\section{Discussion}

Deregulated expression of PAR complex components has been associated to cancer development and spread (19). Nevertheless, no studies have attempted to investigate their expression and role in thyroid cancer progression to date. To the best of our knowledge, only one study evidenced the homozygous deletion of PARD $3 \alpha$ in primary ATC derived cell lines. The authors also reported that the reinstatement of PARD $3 \alpha$ by exogenous expression was able to reduce cell proliferation, motility and invasiveness, and to restore cell-cell contacts and cell adhesion $(38,39)$.

In this case study, we analyzed the mRNA levels of the paralogous genes encoding for PAR complex components in PTC and ATC tissues. The results indicated that the expression of all these genes was deregulated in PTC, and that all of them were significantly lower in ATC compared to PTC. These observations may suggest that the reduced expression of PAR genes may contribute to TC progression and dedifferentiation, as hypothesized in esophageal squamous cell carcinoma where reduced level of $P A R D 3 \alpha$ transcripts was associated with tumor dedifferentiation (40). On the other hand, other studies reported that the overexpression of $P A R D 3 \alpha$ associates with a poor prognosis in patients affected by hepatocellular carcinoma or clear cell renal carcinoma $(41,42)$. Concerning $P A R D 6 \alpha$ and PARD6 $\beta$, previous studies in breast cancer tissues and cell lines demonstrated an increased expression of both genes and their ability to activate the MEK/ERK signaling pathway increasing the proliferation rate of breast epithelial cells $(43,44)$. However, Cunliffe and colleagues (44) reported that the reduced levels of $P A R D 6 \beta$ protein associated with poorly differentiated breast cancer tissues. Regarding $P A R D 6 \gamma$, our data are in agreement with a study on breast cancer cells suggesting for it a tumor suppressor role (45). Previous findings on ovarian and lung cancers demonstrated an increased expression of $a P K C \iota(46,47)$. Although also in our PTC series $a P K C \iota$ was found upregulated in $37 \%$ of cases, it was reduced in $35 \%$ of cases and further reduced in ATC samples. In interpreting these apparently conflicting data, it may be worth to consider that a possible oncogenic/oncosuppressive role of PAR components could be context dependent, as recently suggested (48-52). However, further functional studies should be performed to assess the pathogenetic role of each PAR complex component in TC progression.

We next evaluated whether the deregulated expression of the different PAR genes could be of any prognostic value. In the univariate statistical analysis, some significant associations emerged with the clinicopathological parameters of PTC patients, among which the association between higher $P A R D 6 \beta$ mRNA levels and $B R A F V^{600 E}$ mutation. A study conducted in mice with BRAF oncogene-dependent PTC demonstrated a higher susceptibility to undergo EMT in response to $T G F \beta$ in the animals with $B R A F^{V 600 E}(53)$. It was previously demonstrated that the $B R A F^{V 600 E}$ mutation induced the $T G F \beta$ secretion by $\mathrm{PCCl} 3$ cell line, and that TGFR- $\beta$ phosphorylates PARD6 on S345 $(54,55)$. Once phosphorylated, PARD6 induces degradation of the GTPase RhoA leading to dissolution of TJs, which is one of the first steps of the EMT phenomenon (56). Hence, the significant association here reported between higher $P A R D 6 \beta$ mRNA levels and $B R A F^{V 600 E}$ mutation may be a sign of these molecular events. However, the most interesting significant association emerged by the univariate statistical analysis was between the low PARD $3 \beta$ mRNA levels and tumor relapses. This result was confirmed by the Kaplan-Meier analysis, and multivariate statistical analysis identified the downregulation of PARD $3 \beta$ mRNA as an independent prognostic factor for DFI. This could be of some clinical relevance since, to date, the prognosis of PTC patients still relies on clinicopathological variables such as patient's age, tumor size, histology, lymph node or distant metastasis, which are not accurate in predicting the long-term outcome (57-60). Therefore, the identification of new molecular biomarkers strictly related to the risk of PTC relapse is sorely needed.

In conclusion, the data here reported, although needing to be confirmed by means of larger case-studies, demonstrate that the expression of PAR complex members is deregulated in the majority of PTC. Besides, there is a general trend towards their reduction in ATC tissues, which could be either an effect or a cause of the loss of tissue architecture integrity occurring in undifferentiated tumors. Functional studies are required to assess the actual contribution of PAR complex alterations in TC progression and dedifferentiation. Moreover, $P A R D 3 \beta$ mRNA could represent a useful prognostic biomarker for PTC patients.

\section{Acknowledgements}

The present study was supported by the Sapienza University of Rome grants (grant nos. C26A14RNFY and C26N145E4T, 2014).

\section{References}

1. Cove DJ,Hope IA and Quatrano RS: Polarity in biological systems. In: Development Genetics, Epigenetics and Environmental Regulation. Russo VEA, Cove DJ, Edgar LG, Jaenish R and Salamini F (eds). Springer-Verlag, New York, pp507-524, 1999.

2. Sebbagh $M$ and Borg JP: Insight into planar cell polarity. Exp Cell Res 328: 284-295, 2014.

3. Lee M and Vasioukhin V: Cell polarity and cancer - cell and tissue polarity as a non-canonical tumor suppressor. J Cell Sci 121: 1141-1150, 2008.

4. Assémat E, Bazellières E, Pallesi-Pocachard E, Le Bivic A and Massey-Harroche D: Polarity complex proteins. Biochim Biophys Acta 1778: 614-630, 2008.

5. Khursheed M and Bashyam MD: Apico-basal polarity complex and cancer. J Biosci 39: 145-155, 2014.

6. Lin WH, Asmann YW and Anastasiadis PZ: Expression of polarity genes in human cancer. Cancer Inform 14 (Suppl. 3): $15-28,2015$. 
7. Kemphues KJ, Priess JR, Morton DG and Cheng NS Identification of genes required for cytoplasmic localization in early C. elegans embryos. Cell 52: 311-320, 1988.

8. Tepass U, Theres $\mathrm{C}$ and Knust E: crumbs encodes an EGF-like protein expressed on apical membranes of Drosophila epithelial cells and required for organization of epithelia. Cell 61: 787-799, 1990.

9. Bilder D and Perrimon N: Localization of apical epithelial determinants by the basolateral PDZ protein Scribble. Nature 403: 676-680, 2000.

10. Royer C and Lu X: Epithelial cell polarity: A major gatekeeper against cancer? Cell Death Differ 18: 1470-1477, 2011.

11. Gandalovičová A, Vomastek T, Rosel D and Brábek J: Cell polarity signaling in the plasticity of cancer cell invasiveness. Oncotarget 7: 25022-25049, 2016.

12. Lin D, Edwards AS, Fawcett JP, Mbamalu G, Scott JD and Pawson T: A mammalian PAR-3-PAR-6 complex implicated in Cdc42/Rac1 and aPKC signalling and cell polarity. Nat Cell Biol 2: 540-547, 2000

13. Vinot S, Le T, Maro B and Louvet-Vallée S: Two PAR6 proteins become asymmetrically localized during establishment of polarity in mouse oocytes. Curr Biol 14: 520-525, 2004.

14. Louvet-Vallée S, Vinot S and Maro B: Mitotic spindles and cleavage planes are oriented randomly in the two-cell mouse embryo. Curr Biol 15: 464-469, 2005.

15. Vinot S, Le T, Ohno S, Pawson T, Maro B and Louvet-Vallée S: Asymmetric distribution of PAR proteins in the mouse embryo begins at the 8-cell stage during compaction. Dev Biol 282: 307-319, 2005 .

16. Kohjima M, Noda Y, Takeya R, Saito N, Takeuchi K and Sumimoto H: PAR3beta, a novel homologue of the cell polarity protein PAR3, localizes to tight junctions. Biochem Biophys Res Commun 299: 641-646, 2002.

17. Cline EG and Nelson WJ: Characterization of mammalian Par 6 as a dual-location protein. Mol Cell Biol 27: 4431-4443, 2007.

18. Dormoy V, Tormanen K and Sütterlin C: Par6 $\gamma$ is at the mother centriole and controls centrosomal protein composition through a Par6a-dependent pathway. J Cell Sci 126: 860-870, 2013.

19. Ellenbroek SI, Iden S and Collard JG: Cell polarity proteins and cancer. Semin Cancer Biol 22: 208-215, 2012.

20. Davies L and Welch HG: Increasing incidence of thyroid cancer in the United States, 1973-2002. JAMA 295: 2164-2167, 2006.

21. Jemal A, Siegel R, Ward E, Hao Y, Xu J and Thun MJ: Cancer statistics, 2009. CA Cancer J Clin 59: 225-249, 2009.

22. Kinder BK: Well differentiated thyroid cancer. Curr Opin Oncol 15: 71-77, 2003

23. Pasieka JL: Anaplastic thyroid cancer. Curr Opin Oncol 15 78-83, 2003.

24. Nikiforov YE, Biddinger PW and Thompson LDR: Diagnostic Pathology and Molecular Genetics of the Thyroid. Lippincott Williams \& Wilkins, Philadelphia, 2009.

25. Cancer Genome Atlas Research Network: Integrated genomic characterization of papillary thyroid carcinoma. Cell 159 : 676-690, 2014

26. Kimura ET, Nikiforova MN, Zhu Z, Knauf JA, Nikiforov YE and Fagin JA: High prevalence of BRAF mutations in thyroid cancer: Genetic evidence for constitutive activation of the RET/PTC-RAS-BRAF signaling pathway in papillary thyroid carcinoma. Cancer Res 63: 1454-1457, 2003.

27. Soares P, Trovisco V, Rocha AS, Lima J, Castro P, Preto A, Máximo V, Botelho T, Seruca R and Sobrinho-Simões M: BRAF mutations and RET/PTC rearrangements are alternative events in the etiopathogenesis of PTC. Oncogene 22: 4578-4580, 2003.

28. Elisei R, Ugolini C, Viola D, Lupi C, Biagini A, Giannini R, Romei C, Miccoli P, Pinchera A and Basolo F: BRAF ${ }^{\mathrm{V} 600 \mathrm{E}}$ mutation and outcome of patients with papillary thyroid carcinoma: A 15-year median follow-up study. J Clin Endocrinol Metab 93: 3943-3949, 2008.

29. Kerjaschki D, Krisch K, Sleyter UB, Umrath W, Jakesz R, Depisch D, Kokoschka R and Hörandner H: The structure of tight junctions in human thyroid tumors. A systematic freezefracture study. Am J Pathol 96: 207-226, 1979.

30. Fluge $\varnothing$, Haugen DR, Lillehaug JR and Varhaug JE: Difference in patterns of Met expression in papillary thyroid carcinomas and nonneoplastic thyroid tissue. World J Surg 25: 623-631, 2001.

31. Bai Y, Kakudo K, Nakamura M, Ozaki T, Li Y, Liu Z, Mori I, Miyauchi A and Zhou G: Loss of cellular polarity/cohesiveness in the invasive front of papillary thyroid carcinoma and periostin expression. Cancer Lett 281: 188-195, 2009.
32. Hedinger C, Williams ED and Sobin LH: The WHO histological classification of thyroid tumors: a commentary on the second edition. Cancer 63: 908-911, 1989.

33. Barollo S, Pennelli G, Vianello F, Watutantrige Fernando S, Negro I, Merante Boschin I, Pelizzo MR, Rugge M, Mantero F, Nacamulli $\mathrm{D}$, et al: BRAF in primary and recurrent papillary thyroid cancers: The relationship with ${ }^{131} \mathrm{I}$ and $2-\left[{ }^{18} \mathrm{~F}\right]$ fluoro-2deoxy-D-glucose uptake ability. Eur J Endocrinol 163: 659-663, 2010 .

34. Chomczynski P and Sacchi N: Single-step method of RNA isolation by acid guanidinium thiocyanate-phenol-chloroform extraction. Anal Biochem 162: 156-159, 1987.

35. Vandesompele J, De Preter K, Pattyn F, Poppe B, Van Roy N, De Paepe A and Speleman F: Accurate normalization of real-time quantitative RT-PCR data by geometric averaging of multiple internal control genes. Genome Biol 3, Research0034 (2002).

36. Ulisse S, Baldini E, Sorrenti S, Barollo S, Prinzi N, Catania A, Nesca A, Gnessi L, Pelizzo MR, Mian C, et al: In papillary thyroid carcinoma BRAF ${ }^{\mathrm{V} 600 \mathrm{E}}$ is associated with increased expression of the urokinase plasminogen activator and its cognate receptor, but not with disease-free interval. Clin Endocrinol (Oxf) 77: 780-786, 2012.

37. Livak KJ and Schmittgen TD: Analysis of relative gene expression data using real-time quantitative PCR and the $2^{-\Delta \Delta C T}$ method. Methods 25: 402-408, 2001.

38. Bradford MM: A rapid and sensitive method for the quantitation of microgram quantities of protein utilizing the principle of protein-dye binding. Anal Biochem 72: 248-254, 1976.

39. Garg M, Okamoto R, Nagata Y, Kanojia D, Venkatesan S, Anand MT, Braunstein GD, Said JW, Doan NB, Ho Q, et al: Establishment and characterization of novel human primary and metastatic anaplastic thyroid cancer cell lines and their genomic evolution over a year as a primagraft. J Clin Endocrinol Metab 100: 725-735, 2015.

40. Zen K, Yasui K, Gen Y, Dohi O, Wakabayashi N, Mitsufuji S, Itoh Y, Zen Y, Nakanuma Y, Taniwaki M, et al: Defective expression of polarity protein PAR-3 gene (PARD3) in esophageal squamous cell carcinoma. Oncogene 28: 2910-2918, 2009.

41. Jan YJ, Ko BS, Liu TA, Wu YM, Liang SM, Chen SC, Wang J and Liou JY: Expression of partitioning defective 3 (Par-3) for predicting extrahepatic metastasis and survival with hepatocellular carcinoma. Int J Mol Sci 14: 1684-1697, 2013.

42. Dugay F, Le Goff X, Rioux-Leclerq N, Chesnel F, Jouan F, Henry C, Cabillic F, Verhoest G, Vigneau C, Arlot-Bonnemains Y, et al: Overexpression of the polarity protein PAR-3 in clear cell renal cell carcinoma is associated with poor prognosis. Int $\mathbf{J}$ Cancer 134: 2051-2060, 2014.

43. Nolan ME, Aranda V, Lee S, Lakshmi B, Basu S, Allred DC and Muthuswamy SK: The polarity protein Par6 induces cell proliferation and is overexpressed in breast cancer. Cancer Res 68: 8201-8209, 2008.

44. Cunliffe HE, Jiang Y, Fornace KM, Yang F and Meltzer PS: PAR6B is required for tight junction formation and activated PKC $\zeta$ localization in breast cancer. Am J Cancer Res 2: 478-491, 2012.

45. Marques E, Englund JI, Tervonen TA, Virkunen E, Laakso M, Myllynen M, Mäkelä A, Ahvenainen M, Lepikhova T, Monni O, et al: Par6G suppresses cell proliferation and is targeted by loss-of-function mutations in multiple cancers. Oncogene 35 : 1386-1398, 2016

46. Eder AM, Sui X, Rosen DG, Nolden LK, Cheng KW, Lahad JP, Kango-Singh M, Lu KH, Warneke CL, Atkinson EN, et al: Atypical PKCiota contributes to poor prognosis through loss of apical-basal polarity and cyclin E overexpression in ovarian cancer. Proc Natl Acad Sci USA 102: 12519-12524, 2005.

47. Regala RP, Weems C, Jamieson L, Khoor A, Edell ES, Lohse CM and Fields AP: Atypical protein kinase $\mathrm{C}$ iota is an oncogene in human non-small cell lung cancer. Cancer Res 65: 8905-8911, 2005.

48. Iden S, van Riel WE, Schäfer R, Song JY, Hirose T, Ohno S and Collard JG: Tumor type-dependent function of the par3 polarity protein in skin tumorigenesis. Cancer Cell 22: 389-403, 2012.

49. Yao S, Bee A, Brewer D, Dodson A, Beesley C, Ke Y, Ambroisine L, Fisher G, Møller H, Dickinson T, et al: PRKC- $\delta$ expression promotes the aggressive phenotype of human prostate cancer cells and is a novel target for therapeutic intervention. Genes Cancer 1: 444-464, 2010. 
50. Awadelkarim KD, Callens C, Rossé C, Susini A, Vacher S, Rouleau E, Lidereau R and Bièche I: Quantification of PKC family genes in sporadic breast cancer by qRT-PCR: Evidence that $\mathrm{PKCl} / \lambda$ overexpression is an independent prognostic factor. Int J Cancer 131: 2852-2862, 2012.

51. Ma L, Tao Y, Duran A, Llado V, Galvez A, Barger JF, Castilla EA, Chen J, Yajima T, Porollo A, et al: Control of nutrient stressinduced metabolic reprogramming by $\mathrm{PKC} \zeta$ in tumorigenesis. Cell 152: 599-611, 2013.

52. Namdarian B, Wong E, Galea R, Pedersen J, Chin X, Speirs R, Humbert PO, Costello AJ, Corcoran NM and Hovens CM: Loss of APKC expression independently predicts tumor recurrence in superficial bladder cancers. Urol Oncol 31: 649-655, 2013.

53. Knauf JA, Sartor MA, Medvedovic M, Lundsmith E, Ryder M, Salzano M, Nikiforov YE, Giordano TJ, Ghossein RA and Fagin JA: Progression of BRAF-induced thyroid cancer is associated with epithelial-mesenchymal transition requiring concomitant MAP kinase and TGF $\beta$ signaling. Oncogene 30: 3153-3162, 2011

54. Riesco-Eizaguirre G, Rodríguez I, De la Vieja A, Costamagna E, Carrasco N, Nistal $M$ and Santisteban P: The BRAF ${ }^{\mathrm{V} 600 \mathrm{E}}$ oncogene induces transforming growth factor beta secretion leading to sodium iodide symporter repression and increased malignancy in thyroid cancer. Cancer Res 69: 8317-8325, 2009.

55. Ozdamar B, Bose R, Barrios-Rodiles M, Wang HR, Zhang Y and Wrana JL: Regulation of the polarity protein Par6 by TGFbeta receptors controls epithelial cell plasticity. Science 307: 1603-1609, 2005.
56. Gunaratne A, Thai BL and Di Guglielmo GM: Atypical protein kinase $\mathrm{C}$ phosphorylates Par6 and facilitates transforming growth factor $\beta$-induced epithelial-to-mesenchymal transition. Mol Cell Biol 33: 874-886, 2013

57. Gospodarowicz MK, Henson DE, Hutter RVP, O'Sullivan B, Sobin LH and Wittekind CL: Prognostic Factors in Cancer. 2nd edition. Wiley-Liss, New York, 2001.

58. Passler C, Scheuba C, Prager G, Kaczirek K, Kaserer K, Zettinig G and Niederle B: Prognostic factors of papillary and follicular thyroid cancer: Differences in an iodine-replete endemic goiter region. Endocr Relat Cancer 11: 131-139, 2004.

59. Baldini E, Sorrenti S, Tuccilli C, Prinzi N, Coccaro C, Catania A, Filippini A, Bononi M, De Antoni E, D'Armiento M, et al: Emerging molecular markers for the prognosis of differentiated thyroid cancer patients. Int J Surg 12 (Suppl 1): S52-S56, 2014.

60. Ulisse S, Baldini E, Sorrenti S, Barollo S, Gnessi L, Catania A, Pellizzo MR, Nardi F, Mian C, De Antoni E, et al: High expression of the urokinase plasminogen activator and its cognate receptor associates with advanced stages and reduced diseasefree interval in papillary thyroid carcinoma. J Clin Endocrinol Metab 96: 504-508, 2011. 